\title{
MEASURING THE PRICE OF LABOUR IN AGRICULTURAL ECONOMIES: THE SHADOW WAGE RATE
}

\author{
Bishnu Prasad Sharma (Ph.D)*
}

\begin{abstract}
Labour market imperfections are one of the leading causes of economic backwardness that result in under utilization of labour, the most important input in production process. Labour markets are shallow in subsistence agricultural economies which causes problem in determining the wage rate. The household production function provides an alternative to estimating the shadow wage rate such that it reflects the opportunity cost of labour. The most important deductions of the household production function are: the marginal productivity of labour is its shadow wage rate and; at equilibrium, the marginal returns from labour are exactly equal across all activities. This paper uses data collected in 2008 in course of a leasehold forestry study from 297 households from Makwanpur district of Nepal using a multi stage sampling. This paper estimates the marginal productivity of labour in maize production, the most common form of economic activity, for male and female labour. It examines how the money wage rate and the actual wage rate may differ from the shadow wage rate reflected by marginal productivity of labour in agriculture. The findings reveal that the actual wage rate for male labour is inflated and exceeds its marginal productivity while female wage rate slightly understates its marginal productivity. The paper concludes with policy recommendation of ensuring institutional mechanisms to correct for these imperfections.
\end{abstract}

Key Words: labour market, marginal productivity, shadow wage

\section{INTRODUCTION}

Labour market imperfections are one of the leading causes of economic backwardness. This is because human labour is the most important input to mobilize other inputs in the production process. The value of human labour becomes implicit in value of the products reflected in their market prices. However, there will be high possibility of over or under-pricing if the labour market is not perfect. Under/over pricing of labour creates problems in efficiency as well equity in the production and distribution of goods and services. Although most of the economists believe prevailing wage rate as the price of labour, indeed the wage rate may not be the actual price of the labour because of number of reasons: market is not perfectly functional, or market is too shallow when it exists at all.

\footnotetext{
* Mr. Sharma is Associate Professor of Economics at Patan Multiple Campus, Tribhuvan University, Nepal The Author is thankful to Dr. Shiva Raj Adhikari and Madhav Prasad Dahal for their comments and suggestion on the paper.
} 
Value of human labour is also pivotal from several other economic aspects. In cases of several goods for which market does not exist, such as environmental goods or services, the value of human labour implicit in its collection may serve as a basis for valuation. The value of forest products such as firewood, for instance, is reflected in the labour embodied in course of its collection and transportation (Amacher, Hyde \& Kanel, 1996; Bluffstone, 1995). Value of labour time is also important in estimating the economic impact of interventions that are aimed towards reducing human work time and effort (Sharma, 2011). Measurement of economic impact of technical and institutional innovations that reduce drudgery of rural women in fetching drinking water, collecting firewood, grinding milling, for instance, requires valuation of human labour time.

General economic theory states that the market wage rate determined through the interaction of the forces of demand for and supply of labour is the best measure of the value of labour. This is true only when labour market is perfect. In conditions where labour market are imperfect even if it exits, estimating the value of labour becomes tricky. The wage rate under non-labour market or shallow labour market condition is called shadow wage rate in labour market literature and is widely used in social accounting such as cost benefit analysis. The shadow wage rate should reflect the opportunity cost of labour. The opportunity cost of labour is close to its marginal productivity under giver resource circumstances.

An earlier study by Thapa (2003) had estimated the shadow wage rate in the rural areas of eastern Terai of Nepal during the 1980s. This study estimated the shadow wage rate difference between the family and hired labour and had concluded that hired labour have 25 percent lower marginal productivity than family labour. However, this study did not estimate the marginal productivity for male and female labour separately. Most importantly, it did not analyze the difference between the prevailing market wage rate and the shadow wage of labour.

With changing structure of the society, female labour force participation has increased significantly. For instance, female participation in labour force has increased from 74 to 79 percent during 2003 to 2010 (CBS, 2004; CBS, 2011). Similarly, due to introduction of improved farming inputs and technology such as genetically modified seeds and chemical fertilizers (CBS, 2010), the productivity of labour force has also changed. Thus, there is a need for updated shadow wage rate estimation consistent with recent technology and labour force participation rates at frequent intervals. This will also provide information on labour market situation and a guideline for fixation of minimum wage rate by the government to enhance effective labour market operation. This paper aims to fill up this caveat by producing this information. The objective of this paper is to estimate shadow wage rate in rural area separately for male and female labour and examine its consistency with the prevailing rural market wage rate. The findings from this paper has policy implications for correcting wage rates in par with 
the marginal productivity of labour and emphasizing labour productivity enhancing technological interventions.

\section{STUDY METHODS}

The shadow wage rate estimation should reflect the opportunity cost of labour, the return from utilizing labour in second best productive activity. If the market is perfect, shadow wage is equal to market wage rate; if not shadow wage rate can serve as a guide to correct the over or under stated wage rate. Estimation of shadow wage rate is not straight forward. Several methods are suggested in the literature (Amacher, Hyde \& Kanel, 1996). This paper focuses on rural labour market and uses agriculture production approach to estimate the shadow wage rate. The household production function approach provides tools to estimate the marginal productivity of labour (Sadoulet \& De Janvry, 1995). Besides shadow wage rate, there are other terminologies related to wage rate in practice. They are the nominal wage rate, the real wage rate, effective wage rate etc. Nominal wage rate refers to the wage rate expressed in monetary terms without reference to its purchasing power. The real wage rate on the other hand is a measure of the value of labour in reference to the purchasing power in a given base year. The concept of effective wage rate is used when there are costs involved on the part of the worker in course of participating in the labour market (Skoufias, 1994). For instance, when rural labour temporarily migrates to the cities for work, the cost of transportation, living cost etc. reduce their net earnings from labour. The net wage rate after deducting these costs is considered effective wage rate. Besides, the wage rate paid in cash and wage rate paid in kind also need consideration. In subsistence agricultural sector, labour is paid both in cash as well as kind. In addition to monetary wage rate, labour is provided with food, drinks and smoking for greater efficiency in their work. The cost of these goods provided in kind also adds to the wage paid to the labour. We might call this wage rate actual wage rate.

\subsection{The Household Production Function}

The theoretical model of household production function is based on the assumption of a conventional utility maximizing household subject to the various constraints in the context of a rural community. Following Skoufias (1994), we assume that the household allocate each of its members' time endowment (T) among four main activities: leisure $\left(\mathrm{L}_{\mathrm{i}}\right)$, household production $\left(\mathrm{N}_{\mathrm{i}}\right)$ such as cooking food, fetching water etc, market work $\left(\mathrm{M}_{\mathrm{i}}\right)$ and farm work $\left(\mathrm{F}_{\mathrm{i}}\right)$ where i refers to male $(\mathrm{m})$ and female $(\mathrm{f})$. Households allocate time to work in the market that yields wage income that allows people to purchase market goods $\left(X_{M}\right)$. The effective real wage rate for off farm work $\mathrm{Wi}$, is assumed to be constant. Time devoted to household production combined with other fixed inputs (denoted by $\mathrm{K}$ ) yields a household produced commodity (e.g., food-grain) defined by the production function $\mathrm{Y}=\mathrm{Y}\left(\mathrm{N}_{\mathrm{m}}, \mathrm{N}_{\mathrm{f}}, \mathrm{K}\right)$. The household produced commodity $\mathrm{Z}$ is assumed to be perfectly substitutable with composite agriculture commodity that 
is either produced by the household or purchased from the market. The price of the composite agricultural commodity is used as a numeraire.

The production function of the composite agricultural commodity produced by the household is assumed to be a concave function of $\left(\mathrm{F}_{\mathrm{m}^{\prime}}, \mathrm{F}_{\mathrm{f}^{\prime}} \mathrm{H}_{\mathrm{m}^{\prime}} \mathrm{H}_{\mathrm{f}^{\prime}} \mathrm{A}\right)$, where $\mathrm{F}_{\mathrm{m}}$ and $F_{f}$ are family male and female labour and $H_{m}$ and $H_{f}$ are hired male and female labours and $\mathrm{A}$ is a vector of fixed factors such as agricultural land. It is assumed that hired male and female labours are paid corresponding real wage rates $\mathrm{W}_{\mathrm{m}}{ }^{\mathrm{H}}$ and $\mathrm{W}_{\mathrm{f}}^{\mathrm{H}}$ . It is also assumed that the effective wages received by family members working off the farm may differ from the wages paid to hired labour due to transportation and other costs. Given these specification, the choice variable at the household's hand are $\mathrm{X}_{\mathrm{M}}, \mathrm{N}_{\mathrm{i}}, \mathrm{F}_{\mathrm{i}}, \mathrm{M}_{\mathrm{i}}, \mathrm{H}_{\mathrm{i}}$ so as to

$\max \mathrm{U}\left(\mathrm{C}, \mathrm{L}_{\mathrm{m}}, \mathrm{F}_{\mathrm{H}}, \mathrm{L}_{\mathrm{f}} ; \mathrm{B}\right)$

Subject to

$$
\begin{aligned}
& C=X_{M}+Z \\
& Z=Z\left(N_{m}, N_{f} ; K\right) \\
& X_{M}=\left(F_{m}, F_{f} H_{m}, H_{f} ; A\right)-W_{m}^{H} H_{m}-W_{f}^{H} H_{f}+W_{m} M_{m}+W_{f} M_{f}+V \\
& L_{i}+N_{i}+F_{i}+M_{i}=T \\
& M_{i} \geq 0, i=m, f
\end{aligned}
$$

where $C$ is the total household consumption, the sum of market purchased and home produced agricultural commodity, B is a vector of individual and household characteristics influencing preferences, and $\mathrm{V}$ is real non-labour income.

The Lagrangian function with the constraints can be written as:

$$
\left.\begin{array}{rl} 
& \mathrm{U}\left[\mathrm{X}_{\mathrm{M}}+\mathrm{Z}\left(\mathrm{N}_{\mathrm{m}}, \mathrm{N}_{\mathrm{f}} ; \mathrm{K}\right) \mathrm{T}-\mathrm{M}_{\mathrm{m}}-\mathrm{F}_{\mathrm{m}}-\mathrm{N}_{\mathrm{m}}, \mathrm{T}-\mathrm{M}_{\mathrm{f}}-\mathrm{F}_{\mathrm{f}}-\mathrm{N}_{\mathrm{f}} ; \mathrm{B}\right] \\
+ & \lambda\left[\Gamma\left(\mathrm{F}_{\mathrm{m}}, \mathrm{F}_{\mathrm{f}}, \mathrm{H}_{\mathrm{m}}, \mathrm{H}_{\mathrm{f}} ; \mathrm{A}\right)-\mathrm{W}_{\mathrm{m}}^{\mathrm{H}} \mathrm{H}_{\mathrm{m}}-\mathrm{W}_{\mathrm{f}}^{\mathrm{H}_{\mathrm{f}}}+\mathrm{W}_{\mathrm{m}} \mathrm{M}_{\mathrm{m}}+\mathrm{W}_{\mathrm{f}} \mathrm{M}_{\mathrm{f}}+\mathrm{V}-\mathrm{X}_{\mathrm{M}}\right] \\
+ & \mu_{\mathrm{m}} \mathrm{M}_{\mathrm{m}}+\mu_{\mathrm{f}} \mathrm{M}_{\mathrm{f}}
\end{array}\right\}
$$

Maximizing with respect to $\mathrm{X}_{\mathrm{M}^{\prime}} \mathrm{N}_{\mathrm{i}^{\prime}} \mathrm{F}_{\mathrm{i}^{\prime}} \mathrm{M}_{\mathrm{i}^{\prime}} \mathrm{H}_{\mathrm{i}}$

Where $\mathrm{i}=\mathrm{m}, \mathrm{f}$, yields the following first order conditions, assuming participation in non-leisure activities for the optimal choices of the household.

$$
\frac{\partial U / \partial L i}{\partial U / \partial C}=W i^{*}=W_{i}+\frac{\mu i}{\lambda}
$$




$$
\begin{gathered}
\frac{\partial r}{\partial H i}=W_{i}^{H} \\
\frac{\partial r}{\partial F i}=W_{i}^{*} \\
\frac{\partial Z}{\partial N i}=W_{i}^{*}
\end{gathered}
$$

The equilibrium condition (4b) states that hired labour will be utilized up to the point where the marginal product of the hired labour of each gender is equal to the wage paid to the hired labour. This is the usual first order condition also derived from profit maximization. The equilibrium condition (4a) for household utility maximization implies that households will equate marginal rate of substitution between consumption and leisure of family labour of type $I$ and the shadow wage rate $W_{i}^{*}$ of labour type $I$. The shadow wage rate in turn may be inferred from (4c) and (4d) under a complementary slackness condition for a constrained maximization. If a person is working in the market, his or her shadow wage rate will be equal to the respective effective wage rate $\mathrm{W}_{\mathrm{i}}$ for that gender group. If a person is now working in the market, then the shadow wage rate $W_{i}^{*}$ will in general be greater than $W_{i}$. This also follows the complementary slackness condition.

Thus, for a household that supplies male (female) labour off the farm, the marginal rate of substitution between household consumption and male (female) labour is equal to the effective wage rates for male (female). In addition as implied by condition (4c) and (4d) family male and female labour on the farm or at home is equal to the respective effective wage rate. For households that do not supply any male or female labour to the market, the optimum will occur at the point where the marginal rate of substitution between leisure and consumption is equal to the marginal productivity of male or female labour on the farm. This also implies that people will prefer to enjoy leisure and not work if they consider the marginal utility for leisure is equal or higher than the utility from the work.

The household engages in agriculture and livestock raising (A), forest management (F), and wage labour (including remittance). The $\mathrm{HH}$ seek to maximize a single utility function which depends upon consumption of agricultural goods $\left(\mathrm{A}_{\mathrm{H}}\right)$, market goods $\left(\mathrm{M}_{\mathrm{H}}\right)$, forestry goods $\left(\mathrm{F}_{\mathrm{H}}\right)$, home time $\left(\mathrm{T}_{\mathrm{H}}\right)$ with $\mathrm{HH}$ utility is conditioned on preferences $(\Phi)$ determined by HH (demographic, socio-economic) characteristics.

Thus in conclusion, the shadow wage rate for the male and female labour not participating in market wage work is equal to their marginal productivity in farm production. For this reason, the marginal productivity of labour in farm production can be considered as the measure of the shadow wage rate in the study. Shadow 
wage rate in a community is estimated by measuring the marginal productivity of labour in activities common to most households. For instance, the average marginal productivity per day can be measured as the revenue from the sales of fishes caught from a nearby stream or the value fetched by a load of firewood fetched in the nearby market. However, since these activities were not common to all households, maize production which was practiced by 95 percent households was chosen as an activity for estimating shadow wage rate.

\subsection{The Model}

Estimating the value of labour time was based on estimating the marginal productivity of labour. This study uses the Cobb-Douglas technology to measure marginal productivity of labour and other inputs that is common in several similar studies such as Quisumbing (1996), Thapa (2003) including others.

$\operatorname{lnMAIZE} \_$OUTPUT $=\beta_{0}+\beta_{1} \operatorname{lnMALE}+\beta_{2} \operatorname{lnFEMALE}+\beta_{3} \operatorname{lnLAND}+\beta_{4} \operatorname{lnBULLOCKS}$ $+\beta_{5} \operatorname{lnCOMPOST}+\beta_{6} \operatorname{lnCHEMICAL}+\mathrm{e}$

Where, MAIZE_OUTPUT is the value of composite output of maize in Rupees terms, (MALE) and (FEMALE) are male and female hours of labour used, (LAND) is the area of cultivation plot for maize in hectares, (BULLOCK) is the hours of bullock used, (COMPOST) the loads of compost manure used, (CHEMICAL) is the kilograms of chemical fertilizers used and e is the stochastic error term. There was a common practice of family labour exchange during peak agricultural seasons and considering the homogeneity of labour characteristics, this study does not differentiate between family labour and exchange labour.

The regression coefficients multiplied by a quotient of the value of output and respective input (for e.g. [MAIZE_OUTPUT/MALE] in case of the male labour) gives the marginal productivity of male labour in NRs terms while the coefficient $\beta_{1}$ is the elasticity coefficient.

A comparison of shadow wage rate with actual wage rate (in cash plus in kind) has been made for analyzing the variation of the shadow wage rate with actual wage rate.

\subsection{Sampling Procedure and Data}

This paper uses the micro data collected for a different purpose through primary survey of 297 households from Makwanpur, a mid hill district of Nepal, in course of a study on leasehold forestry (LHF) in 2008. Leasehold forests are government owned degraded forest lands provided to identify poor households on a 40 year lease for regeneration and livelihood. The study was designed for analyzing the impact of LHF in household income and welfare. We limit discussion of this paper to the estimation of the estimation of the shadow wage rate and a comparative analysis with market and actual wage rate. 
Regarding the sampling design for the primary survey, a multi stage sampling was conducted to select the VDC, the LHF groups and the households in a sequential order. Firstly, 12 VDCs were selected out of 23 VDCs. At the second stage, 5 LHF groups were randomly selected from each VDC. In the third stage, from among the selected LHF groups, all available households were selected. Out of expected 300 households, data was collected from 297 households.

This paper uses information related to estimation of the marginal product of labour in maize production. This information consists of the area of the largest plot of maize cultivation, total maize production and maize price, number of male and female labours employed during various stages, units of bullocks used, loads of compost manure used and chemical fertilizers used. Information was also collected on the prevailing cash wage rate they had to pay to labour if they had to hire labour in agricultural activities. The information on the cost of in-kind goods provided to labour was also collected. No separate data was collected for cost of in-kind food, drinks and smoking by gender for simplicity. The shadow wage rate is estimated from the marginal productivity of labour in maize production. It is estimated separately for male and female labour. The actual wage rate is the sum of wage rate paid in kind to hired labour and the cost of goods provided in kind. The field data from the study was first of all entered in the data entry software CSPro.4 while all statistical analysis was conducted using the statistical software STATA 10.

\section{RESULTS}

The Cobb-Douglas technology was used for estimating the marginal productivity of inputs, particularly labour, male or female. The descriptive statistics of the variables is provided in Table 1. Male labour constituted relatively small share of the total labour force in maize production. Some households did not use any male labour while there were no households not using female labour. Some households had used tractors for agricultural operations such as ploughing. The tractor hours were converted into bullock hours using appropriate conversion factors (1: 12.63) based on field experience.

Table 1. Descriptive statistics of the maize production function variables used in regression equation

\begin{tabular}{lcccc}
\hline \multicolumn{1}{c}{ Variables } & Mean & Std. dev & Minimum & Maximum \\
\hline MAIZE OUTPUT (in Rs) & 6093.064 & 4311.231 & 304 & 27000 \\
MALE (hrs) & 106.3401 & 71.069 & 0 & 457.75 \\
FEMALE (hrs) & 144.02 & 86.98 & 2 & 528 \\
LAND (in hectare) & 0.33 & 0.21 & 0.033865 & 1.36 \\
BULLOCKS hrs) & 41.77 & 30.426 & 0.00 & 195 \\
COMPOST (loads) & 133.46 & 104.74 & 3 & 1000 \\
CHEMICAL(Kgs) & 23.03 & 22.45 & 0.0 & 201 \\
\hline
\end{tabular}

Source: Author's calculation. 
For the estimation of marginal productivity of inputs, the variables were converted into their log values. The regression result of the double log linear form is provided in Table 2 which where the coefficients give a measure of the elasticity The coefficients in the robust double log regressions estimates are the respective elasticities of the production inputs. The male and female labour, bullock used in ploughing and the land used in cultivation appeared to be statistically significant while the compost manure and chemical fertilizers did not turn out to be statistically significant. Multiplying the elasticities of the statistically significant inputs by the ratio of the revenue product and respective inputs provides us the marginal productivities of the respective inputs. Accordingly, the marginal productivities of the respective inputs were estimated.

Table 2. Regression results for estimating the Cobb-Douglas production function (Robust)

\begin{tabular}{ccccc}
\hline Variables & Coeffecients & Std. error & t-ratio & p-value \\
\hline Constant & 6.095773 & 0.447527 & 13.62 & 0.000 \\
lnMALE & $0.116886^{* * *}$ & 0.045085 & 2.59 & 0.010 \\
lnFEMALE & $0.27839^{* * *}$ & 0.059748 & 4.66 & 0.000 \\
lnLAND & $0.203919^{* *}$ & 0.088967 & 2.29 & 0.023 \\
InBULLOCKS & $0.199323^{* * *}$ & 0.065894 & 3.02 & 0.003 \\
InCOMPOST & 0.02506 & 0.042968 & 0.58 & 0.560 \\
InCHEMICAL & 0.003781 & 0.014181 & 0.27 & 0.790 \\
\hline
\end{tabular}

$\mathrm{R}^{2}=0.5222 ;{ }^{*}, * *$ and ${ }^{* * *}$ indicate significant at less than 10,5 and 1 percent respectively;

Source: Author's calculation.

The marginal productivity of labour was estimated NRs 9.0 for male and 13.78 for female labour per hour indicating around 53 percent higher productivity of female labour compared to female labour. The mean value of the marginal productivity of each hectare of land was 4390.39 and ranged between NRs 358 and 15053. The marginal productivity of a pair of bullock was NRs. 38.58 indicating a pair of bullock was equivalent to more than 4 male labour. The estimation coefficients were not statistically significant for compost manure and chemical fertilizers and were not considered for estimating the marginal productivities.

Table 2. Estimates of the marginal productivities of statistically significent variables

\begin{tabular}{lrrrr}
\hline \multicolumn{1}{c}{ Inputs } & \multicolumn{1}{c}{ Mean } & Std. dev & Minimum & Maximum \\
\hline MP male labour (Rs.per hour) & 9.00 & 8.47 & 0.52 & 87.66 \\
MP female labour (Rs.per hour) & 13.78 & 9.19 & 1.20 & 62.64 \\
MP of land (Rs.per hectare) & 4390.39 & 2472.36 & 358.28 & 15053.79 \\
MP of BULLOCK PAIR (Rs.per hr) & 38.58 & 31.016 & 2.07 & 210.12 \\
\hline
\end{tabular}

Source: Author's calculation. 
The average marginal productivity of labour for either male or female was thus NRs. 11.43. We convert the hourly marginal productivity into daily basis with the 8 hours work schedule accepted internationally. This gives an average marginal productivity per day of Rs. 72.00 for male, Rs. 110.24 for female and Rs. 91.44 on average.

As discussed earlier, the seasonal market wage rate consists of two components- the wage paid in cash and the wage paid in kind in the form of food, drinks and smoking. The wage rate in cash combine with the wage paid in kind can be considered as real market wage rate. A comparison of the shadow wage rate measured in terms of marginal productivity of labour, seasonal money wage rate and seasonal real wage rate provide an idea of how price of labour differ under these conditions.

Table 4. Comparison of money wage, actual wage and shadow wage rate (in Rs. per day)

\begin{tabular}{|c|c|c|c|c|c|c|}
\hline \multirow{2}{*}{$\begin{array}{l}\text { Labour } \\
\text { Category }\end{array}$} & \multicolumn{3}{|c|}{$\begin{array}{l}\text { Peak seasonal market wage } \\
\text { rate }\end{array}$} & \multirow{2}{*}{$\begin{array}{l}\text { Shadow } \\
\text { wage rate } \\
\text { (D) }\end{array}$} & \multicolumn{2}{|c|}{$\begin{array}{l}\text { Relative with shadow wage rate } \\
\text { (ratio) }\end{array}$} \\
\hline & $\begin{array}{c}\text { Money } \\
\text { wage } \\
\text { (A) }\end{array}$ & $\begin{array}{l}\text { In kind } \\
\text { wage } \\
\text { (B) }\end{array}$ & $\begin{array}{l}\text { Actual } \\
\text { wage } \\
(\mathrm{C}=\mathrm{A}+\mathrm{B})\end{array}$ & & $\begin{array}{c}\text { Money wage } \\
{[\mathrm{E}=} \\
\left.(\mathrm{D}-\mathrm{A})^{*} 100 / \mathrm{D}\right]\end{array}$ & $\begin{array}{c}\text { Actual wage } \\
{\left[\mathrm{F}=(\mathrm{D}-\mathrm{C})^{*} 100 / \mathrm{D}\right]}\end{array}$ \\
\hline Male & 69.68 & 40.88 & 110.56 & 72.00 & 3.22 & -53.56 \\
\hline Female & 62.80 & 40.88 & 103.68 & 110.24 & 43.03 & 5.95 \\
\hline Average & 66.24 & 40.88 & 107.12 & 91.44 & 27.56 & -17.15 \\
\hline
\end{tabular}

Source: Author's calculation.

The money (in-cash) wage rate was Rs. 69.68 and Rs. 62.80 for male and female labour respectively. The average in-kind wage was Rs. 40.88. The in kind wage rate was not estimated separately for male and female due to homogeneity in consumption pattern. A comparison of the different wage rates indicate that the seasonal money wage rate might be higher or lower than the marginal shadow wage rate measured in terms of the marginal productivity of labour. The result revealed that the shadow wage rate is 3.22 and 43.03 percent higher than the money wage rate for the male and female respectively. The shadow wage rate is 27.56 percent higher than the money wage rate on average. However since labour do not work for cash income only and are provided with expenses in-kind, shadow wage rate comes to be around 53.56 lower than the actual wage rate for male but 5.95 percent greater for the female. On average the shadow wage rate is 17.15 percent lower than the actual wage rate.

\section{DISCUSSIONS}

Prices of goods and services serve two purposes, firstly they provide a measure of value and secondly, they act as incentives in production decision making. Lack of correct price signals leads to either over valuation or under valuation resulting in 
market disequilibrium. Labour market becomes perfect and economic activities flourish when the shadow wage rates are very close to the market wage rate. Such a situation enables decision making by production units with greater accuracy. The household production function provides a guideline to labour allocation related decision making based on utility maximization. One of the important deductions of the household production function is: at equilibrium, the marginal returns to labour are exactly equal across all activities.

The findings from shadow wage rate estimation and the analysis of the cash wage and actual wage provide important insights. The male labour is valued 3.22 percent lower in money wage rate than their marginal productivity, but is valued 53.56 percent higher in actual wage rate compared to their marginal productivity. Regarding the wage rate for female, the productivity of female labour is 43 percent higher than the money wage rate. But their actual wage rate indicate that they are valued slightly highly (5.95 percent) than their marginal productivity. In this sense, the market for female labour is relatively representative of the marginal productivity and is reflective of the true opportunity cost in agricultural operations.

Regarding the labour market for male, the actual wage rate seems to be artificially inflated. Such wrong signals lead to wrong incentive mechanism in economic activities leading to suboptimal utilization of labour force. Though the difference in money wage for male and female labour is small (around 10 percent), the relatively higher (53 percent higher) marginal productivity of female labour makes the hiring male labour relatively uneconomic and keeps them unemployed in agricultural works. In sociocultural situation of Nepal, where males contribute less in household activities, this is likely to put an extra burden of female labour to go for work outside home in addition to her household work.

There are very few studies on the shadow wage rate estimation in the rural context of Nepal for a comparison. One such study based on 1984/85 data by Thapa (2003) had estimated shadow wage rate for rural Terai of Nepal for Rs. 15.70 for family labour and 10.61 for hired labour. No estimate was done separately for male and female labour. Since there is a huge time lag with change in labour force participation rate and state of technology, it would not be appropriate to compare these figures.

In addition to producing information of the opportunity cost of labour, the estimation of shadow wage rate can serve several other purposes in economic analysis. For instance, impacts of various activities and interventions in the society appear in two forms: tangible products and intangible products. Tangible products might be in two forms: marketable and un-marketable. The economic impact of interventions which produce tangible market products are relatively easier to assess. Problem exists in assessing economic impacts of interventions for tangible products for which market does not exist. Environmental goods from land, sea and forest fall in this category. 
Firewood for instance constitutes a significant share in the consumption expenditure of the households. However, due to problem of valuation, value of firewood collected for self use is often left out in household income and consumption statistics. For instance, the standard Living Standard Measurement Survey 2010/11 also excludes the value of firewood collected for self use in household consumption estimates (CBS, 2011).

Several interventions produce non-tangible livelihood benefits that improve welfare of the households. The savings of household time in household chorus such as milling and grinding, fetching water, fetching firewood are examples. This makes it difficult to correctly evaluate the contributions of different interventions with reasonable accuracy. The use of market wage rate might over state or understate the value of such contributions as revealed by the exercise above. The household production function provides a relatively better alternative to estimating the value of labour time.

One limitation of this study is because maize cultivation prevails only during highly productive few months during monsoon when rural people working in the cities also return to villages due to the high productivity during that region. The labour productivity measured in maize production is thus likely to overestimate the shadow wage rate of rural labour in the absence of economic activities for most of the part of the year in areas depending on rain fed agriculture. This makes economic valuation a very tricky issue with likely over estimation or under estimation of the true impact of interventions.

\section{CONCLUSIONS AND POLICY IMPLICATIONS}

This paper estimates the shadow price of labour under shallow labour market condition in subsistence agricultural economy in Makwanpur district of Nepal. In the absence of perfectly functioning market, the shadow wage rate estimation based on marginal productivity of labour provides the closer approximation of the value of labour time. This paper has shown how the prevailing seasonal prices in the labour market may overstate or understate the value of labour.

Regarding policy implications, the findings have revealed that male actual wage rates are inflated over their marginal productivity. Male money wage rate is around 10 percent higher than female wage rate while the female productivity is the reverse. Male marginal productivity is 53 percent lower than that of female. Government policies towards institutional arrangement for enforcing equal money wage rate for male and female can at least reduce this distortion and imperfection in the labour market. Further though male actual wage rate does not reflect its true opportunity cost in alternative use, there is less likelihood of reducing actual wage rate. This is because there is rigidity in downward movement of wage rate. Thus introducing productivity enhancing skills and technological interventions are the most reliable policy alternative to correct the distortion in the labour market in the rural economy. 
One way this is possible is by introducing measures for transforming subsistence agriculture to commercial farming.

\section{References}

Amacher, G.S., Hyde, W.F. \& Kanel, K.R. (1996). Household fuel wood demand and supply in Nepal's Terai and mid-hills: Choice between cash outlays and labor opportunity. World Development, 24, $1725-1736$.

Bluffstone, R.A. (1995). The effect of labour market performance on deforestation in developing countries under open access: An example from rural Nepal. Journal of Environmental Economics and Management, 29, 42-63.

CBS. (2004). Nepal living standards survey 2003/04. Central Bureau of Statistics.

CBS.(2010). Statistical Pocket Book. Central Bureau of Statistics

CBS. (2011). Nepal living standards survey 2010/11. Central Bureau of Statistics.

Key, N., Sadoulet, E. \& De Janvry, A. (2001). Transactions costs and agricultural household supply response. American Journal of Agriculture Economics. 82,245-259

Quisumbing, A.R. (1996). Male-female differences in agricultural productivity: Methodological issues and empirical evidences. World Development. 24, 1579-1595

Sadoulet, E. \& De Janvry, A. (1995). Quantitative development policy analysis. Baltimore: John Hopkins University Press.

Sharma, B.P. (2011). The welfare impacts of leasehold forestry in Nepal. SANDEE Working Paper, WP 61-11.

Skoufias, E. (1994). Using shadow wages to estimate labour supply of agricultural households. American Journal of Agricultural Economics, 76, 215-227.

Thapa, P.J. (2003). Modeling the efficiency of family and hired labour: illustrations from Nepalese agriculture. England: Ashgate Publishing Limited. 